\title{
ABDURRAHMAN WAHID'S CONCEPT OF NON-VIOLENT APPROACH TO BUILDING PEACE
}

\author{
Terrorism Prevention In Indonesia
}

\author{
Muhammad Saiful Mujab \\ Master Student, Vrije Universiteit Amsterdam \\ ssaifulmmujab@yahoo.com
}

\begin{abstract}
Abdurrahman Wahid is a prominent moslem scholar in Indonesia and Indonesia's fourth president (and the first president voted by people's representative council). He was born from traditionalist muslim family. His grand father is Hasyim Asy'ary, the founder of Nahdlatul Ulama', the biggest islamic organization in theworld with 25 million member. ${ }^{1}$ His father, Wahid Hasyim, is the first minister of religious affairs. He was also the chairman of Nahdlatul Ulama' for several periods.His contribution to create peace is countless. He is well known as the father of pluralism in Indonesia. After his death, many people started to fund organizations learning about his thoughts of pluralism, culture and religion, protecting minorities, respecting diversities, creating peace, etc.This article is attempting to explain his non-violance approach to create peace, in the case of terrorism prefention. Firstly, the writer define the term terrorism in general and Abdurrahman Wahid's version. Secondly, it is explained three backgrounds of the emergence of terrorism; (1). the feeling of inferiority (2). Superficial understanding towards religion (3) the weak system of Indonesia government. And the third is the solution of those three causes; (1). Dialogue (2). Islamic Education (3). Improving the system of the government.
\end{abstract}

Keywords: Abdurrahman Wahid, terrorism, peace, non-violence approach.

\section{A. Introduction}

7 he emergence of terrorism, in any religions, is a stumbling block to creating peace and harmony among religious communities lately. It often appears as headlines of newspapers. Before starting the discussion, it is important to know the definition of terrorism. Although some books provide so many definition of terrorism and it actually has a broad meaning, but here is provided two authoritative definitions.

First, the UN Assembly entitled "Measures to Eliminate International Terrorism" defines terrorism as:

\footnotetext{
${ }^{1}$ https://www.britannica.com/biography/Abdurrahman-Wahid, accessed 05 October 2015.
} 
"Criminal acts intended or calculated to provoke a state of terror in the general public" 2

Meanwhile Enders and Sandler, whose definition is cited in many academic essays, said that terrorism is a planned crime of extraordinary harshness in the sake of political change through threatens. ${ }^{3}$ Whittaker defines terrorism as intended production and exploitation of fear or the threat of violence in the pursuit of political chance. ${ }^{4}$ "To sum up, terrorism is a premeditated violence directed at innocent people aiming to change a status quo.

Abdurrahman Wahid argues that the definition of peace and terrorism has changed. The word "peace" in international relationship is now defined as a condition without war or any violence which is done by one side over other sides, along with some conditions and requirements from the winning side. The term terrorism we know is possibly defined from one side of super power countries, so that those who oppose the definition are considered as terrorist. Can the superpower countries refer back its original meaning, namely violence use by those who do not want to negotiate? If this definition applies, so why there are still thousands of innocent peoplefalling as victims of bombing? ${ }^{5}$ What I understand from this statement is that Abdurrahman Wahid cannot accept the aggression of some superpower countries over some other countries to fight against terrorism. From the time he wrote the book, up to know, terrorist actions have been still widely occurring. Let us have a look at a short period of 12-18 November this year, there are 54 attacks, 470 killed, 554 injured, and 11 suicide blasts, in ten countries. ${ }^{6}$

The term terrorism nowadays has close relation to Islam. Some people relate terrorism to the term Jihad. ISIS, for example, attaches Islam in its name and many other organizations name themselves with Islamic connotation. People recognize "allahuakbar" more as a command to attack than a start of performing prayers. Is terrorism always related to religion particularly Islam?

Whereas Islam always tries to state that its teaching is all about peace, even its name translates peace. Abdurrahman Wahid argues that there are only two conditions in which Muslims are allowed to use physical defense. The first is when Muslims' faith is disturbed. ${ }^{7}$ It is in a state when Muslims are forced to convert to other than Islam. And the second is when they are driven out of their houses. It is needed to note that the two

\footnotetext{
${ }^{2}$ http://www.un.org/documents/ga/res/49/a49r060.htm, accessed on 25/11/2015

${ }^{3}$ Enders, W., \& Sandler, T. The effectiveness of antiterrorism policies: A vector-autoregression-intervention analysis. The American Political Science Review.,vol. 87(1993),829

${ }^{4}$ David J. Whittaker, The Terrorism Reader, Oxon; Rouledge, 2007, 10

${ }^{5}$ Abdurrahman Wahid, Islamku, Islam Anda, Islam Kita,Agama Masyarakat NegaraDemokrasi, (Jakarta: The Wahid Institute, 2006), 291

${ }^{6} \mathrm{http}$ //www.thereligionofpeace.com/pages/articles/opinion-polls.aspx, accessed on 25/11/2015

${ }^{7}$ Wahid, Islamku, Islam Anda,111
} 
conditions allow physical defense. It is still debatable whether Muslims are allowed to kill others if their lives are threatened or not. This is how Islam has been working for these centuries without violence, including how Islam came to the country, Indonesia. ${ }^{8}$ This is very contrast with the image of Islam recently all over the world.

The statistics says that Islamic countries remain on the last ranks of peace and Europe on the most peaceful geographical area in the world. According to Institute for Economics and Peace, Global Peace Index 2015, the three least peaceful countries are Syiria (162), Iraq (161), Afghanistan (160), meanwhile Indonesia ranks 46 (56 in 2013). ${ }^{9}$ Considering Indonesia as the largest Muslim population country, this is a good enough achievement. This gradual process, jumping ten numbers, cannot be separated from the role of Islamic figures in the country.

Abdurrahman Wahid is a very influential figure. His contribution to create peace in Indonesia is countless. He is concerned on peace, pluralism and empowering minorities. Even after he suffered from blindeness, a year before his presidency, he said that "this is my destiny, I will be more productive. ${ }^{10} \mathrm{He}$ wrote many articles and delivering peace messages in his speeches.

In this essay, I would like to squeze his concept on non-violance approach to terrorism prevention in Indonesia from his book "Islamku, Islam Anda, Islam Kita,Agama Masyarakat Negara Demokrasi" which roughly translates "My Islam, Your Islam, and Our Islam, The Religion of Democratic Country Society. Here, I would like to elaborate his point of view on the roots of terrorism in Indonesia and some of preventive actions. This very small part of Islam; muslim-fundamentalist-radicals should be over taken everywhere they exist. But this is not the ambition of the essay to cope the whole concept of coping terrorism according to Abdurrahman Wahid. This small essay might take a small part in introducing his thoughts particularly in terrorism prevention.

\section{B. The Causes of Terrorism}

Terrorism is about power; looking for power, and use it to change a status quo. ${ }^{11}$ Abdurrahman Wahid argues that, generally those who get involved in fundamentalist movements are youngsters who are usually technically skillful (kind of young executive) but their psychological background are not traced. What are the backgrounds of this phenomenon?

\footnotetext{
${ }^{8}$ Wahid, Islamku, Islam Anda,346

${ }^{9}$ www.economicsandpeace.org, accessed 25/11/2015

${ }^{10} \mathrm{KH}$. Abdurrahman Wahid \& Daisaku Ikeda, Dialog Peradaban Untuk Toleransi dan Perdamaian, (Jakarta; PT. Kompas Gramedia), 13

${ }^{11}$ Whittaker, The Terrorism Reader,5
} 


\section{Inferiority}

In this era, some Muslims do not believe in their selves and civilization. They are blinded by the sweet memories of golden age of Islam in history. They emotionally see that Islamic world, compared to "western" countries, nowadays are far left behind. They use material measure to compare their lives. Seeing advanced technology and modern infrastructure made them forget Islamic values and its teachings. Whereas in Islam we have to balance our material and spiritual. It is not merely advanced technology or wealthy, but also serenity.

These Muslims try to catch up "western" countries physically by using violence and terror in order to impede that material development and advancement. They prefer to institutionalize Islam but do not believe in the ability of Islamic culture to advance them. But actually the case is if they pay more attention to the culture, their envy and hatred of "western culture" will automatically decrease. ${ }^{12}$ This is inline what Whittaker says that psichologigally, terrorism is a form of personal dissatisfaction with his life and achievent. Terrorists express their antisocial onto others. All they have is "we versus they" outlook. ${ }^{13}$

Considering Islam (Islamic culture) as the best way of life is not wrong. Everybody always thinks that what they believe is the true one. So that's why being different in the way of living a life is natural. This is what God says in surah Al Hujurat verse 13 stating that " $\mathrm{O}$ mankind, indeed We have created you from male and female and made you peoples and tribes that you may know one another. Indeed, the most noble of you in the sight of Allah is the most righteous of you. Indeed, Allah is Knowing and Acquainted". ${ }^{14}$ This difference is fair and even enriches our collective lives, so that we do not need to be afraid of diversity.

Abdurrahman Wahid sees that being different is natural. In other words we can say that being different is undeniable and what is not allowed is segregation. This is in line with the saying of the Qurán surah Ali Imran verse 103 "And hold firmly to the rope of Allah all together and do not become divided".${ }^{15}$ On the contrary, terrorists cannot accept diversities. Their victims are those who have different opinion from them. In this point, Abdurrahman Wahid finds the discrepancy between the stance of a small group ofmuslim and their religious teaching. ${ }^{16}$

2. Superficial Understanding on Religion

The second aspect of the emergence of terrorism is the shallow understanding of these young Muslims towards their own religion. They are mostly mathematician,

\footnotetext{
${ }^{12}$ Wahid, Islamku, Islam Anda,250

${ }^{13}$ Whittaker, The Terrorism Reader, 19

${ }^{14} \mathrm{https}$ ://quran.com/49/13, accessed in 26/11/2015

${ }^{15} \mathrm{https}$ ://quran.com/3/103, accessed in 26/11/2015

${ }^{16} \mathrm{Wahid}$, Islamku, Islam Anda,380
} 
and other exact sciences experts, economists who have rational calculations and doctors who think empirically. For example, Dr. Azhari Husin was a lecturer and mathematician. He studied in Australia for four years. ${ }^{17}$ Nurdin M. Top was an accountant. ${ }^{18}$ These exact sciences require the learners and experts to spend much of their time in the sciences, and they automatically have limited time to study about religion deeply. Therefore they take shortcuts and refer directly to main textual sources of Islam namely the Qurán and prophetic tradition (hadith), regardless of learning various interpretations in the long history of Islam. ${ }^{19}$

Those who do terror actions cannot differentiate between the institution of Islam and the culture of Islam. Those who do not aware of the "culture", must feel that their institution is threatened by western culture in the form of modernization. Automatically, they feel that it is hard to face the challange of modernization. Therefore they use many ways including violence to "maintain" the religion they love. They ignore victims' lives, all they know is to satisfy their feeling of "maintaining" their religion. ${ }^{20}$ This is also related to feeling inferiority.

3. Weak System of the Government.

Abdurrahman Wahid wrote one chapter of his book in 2002. The president of Indonesia was Megawati Soekarno Putri. He argues that national security at the year was weak. That was because the security forces such as police have close relation with terrorists organization and hoodlum. ${ }^{21}$ Some political systems have no effective nonviolent means for the succession to power. ${ }^{22}$ Abdurrahman Wahid mentioned without any proof and clear name- an ocnum of hoodlum preached in front of religious leaders as if he is innocent. Abdurrahman Wahidoften does this, satirizing by mentioning an unidentified ocnum but intentionally referring to someone in order to wait the accused ocnum's response for political purposes. He means that a criminal can be freely speak in front of religious people showing how weak the country was. This paralyzed national security triggered the rise of terror action at the time. Moreover, it was assumed that there is a secret relation between the apparatus and the criminals.

His argumentation on the weak national security is proofed by several facts. Police did not catch some people who were accused to get involved in doing Bali bomb. In addition, despite the fact that Indonesia was in emergency condition of

\footnotetext{
${ }^{17} \mathrm{http}: / /$ www.smh.com.au/articles/2004/09/09/1094530774504.html?from=storylhs, Accessed 25/11/2015

${ }^{18} \mathrm{http}: / /$ news.bbc.co.uk/2/hi/asia-pacific/4302368.stm, Accessed 25/11/2015

${ }^{19}$ Wahid, Islamku, Islam Anda,380

${ }^{20}$ Wahid, Islamku, Islam Anda, 380

${ }^{21}$ Wahid, Islamku, Islam Anda, 292

${ }^{22}$ Whittaker, The Terrorism Reader, 20
} 
terrorism, Hamzah Haz, the vice president of Indonesia at the time, visited Abu Bakar Ba'asyir, who at the time was accused to have an influential decision on planning terrorism action in Indonesia, Singapure and Malaysia, for the sake of brotherhood. ${ }^{23}$ This was not a wise decision. He did not consider his self as a vice president. Brotherhood is a very personal bussiness, whereas terrorism was a national problem.

\section{Soft-Approach to Prefent Terrorism}

\section{Dialogue}

Biggar states that, "human experience confirms that diversity among peoples can be a source of value as well as of conflict", ${ }^{24}$ including religion. Yahezkel Landau, as quoted by Little, religion can fuel extrimism to do violence. ${ }^{25}$ David Little call this group extrimist religion defined as "religion that readily demonizes whole group of people, whether ethnic, national, or religious grounds." ${ }^{26}$ Which "religion" in Islam is categorized in extrimist religion?

Abdurrahman Wahid offered the concept of "My Islam, Your Islam and Our Islam". This concept is fundamental to create peace and tollerantthrough acknowladging diversity, and respecting each others including not to do violance. This article reflects the whole contain of the book and its title is adopted as the tittle of the book since the concept is the heart of his thought.

My Islam means, our personal perception on Islam with our backround shaping it such as education, culture, books we read, people we discuss with and organizations we get involved within. Ulil Abshar Abdalla, A liberal muslim, for example, uses his critical thinking towards religion. His statements are often debatable and criticized by many people. Often he is rejected to attend an invitation, even by university students who should be open to any differences. Up to now, he is banned to enter Malaysia due to his thought. I feel sorry for some of this actions. His thought on Islam is his "My Islam" which has been taking long academic journey in his life. He grew up in traditional Islamic ducations for years and studied in some institution having different affiliation. He studied at LIPIA Jakarta, a university which is funded by Saudi Arabia, Higher Education for Philosophy Driyarkara which affiliates with Christian, and Boston University and Harvard University. So that he has his own perception of Islam.

Your Islam means others' perspectives. Some Muslims in Java became Muslims because they are born in muslim family. They are supposed to do what their parents do such

\footnotetext{
${ }^{23} \mathrm{http}: / / w w w . v o a i n d o n e s i a . c o m / a / a-32-a-2002-05-30-1-1-85128177 / 10735 . h t m l a c c e s s e d ~ 20 / 11 / 2015$

${ }^{24}$ Nigel Biggar, Between Keen and Cosmopolis, An Ethic of the Nation, Eugene; Wipf and Stock, 2014,10

${ }^{25}$ David Little, Peace Makers in Action; Profiles of Religion in Conflic Resolution, (Cambridge: Cambridge University Press, 2007), 430.

${ }^{26}$ Little, Peace Makers in Action, 434
} 
as doing rituals, and many other traditions. Something is considered true because they believe it is true, no criticism is needed. So do other muslim people have their own version of Islam.

And the third one is "Our Islam" which becomes the source of friction and conflict. Our Islam means that My Islam and Your Islam should collaborate to conceptualie how is Our Islam in the future. ${ }^{27}$ The problem is when some people or group try to demand others following their concept by doing physical force, such as terror action.

Dialogue is essential as a free and open way of changing idea and opinion to reach solutions. ${ }^{28}$ Abdurrahman Wahid argues that we (Indonesian) are still not used to do this, dialogue since we had been experiencing stockaded for long time. Since the authoritarian leaders impose their own opinion and enforce their own version of true. The weak of argumentations causes a person closed from argumentation and idea exchange.

Free and open dialogue can reach final truth which is accepted and followed by those who have healthy mind. This is the main value of honesty to maintain the truth, think, argue, and delivering opinion. This is a sign of democratic society. ${ }^{29}$

It is important to respect all idea as long as expressed in physical harshness. If all ideas have been accommodated, sitting together and changing ideas is the best way to reduce fundamentalists' thought which drives them to do violence. In addition, presumably, terror actions echo unlistened voice, unresponded idea, unaccommodated interest. So that's why dialogue is essential.

Islam is a religion respecting diversity. This what made Islam spread in Indonesia peacefully without any violence, war and coercion. The preachers graced local tradition, wisdom and faith, such as Buddhism and Hinduism so that Islam was accepted by the majority of Indonesian society and at the same time keeping local traditions.

Islam recommends, according to Abdurrahman wahid obliges, dialogue as a media to solve problems and compromise any differences, Allah said in the Qur' an "So by mercy from Allah , [O Muhammad], you were lenient with them. And if you had been rude [in speech] and harsh in heart, they would have disbanded from about you. So pardon them and ask forgiveness for them and consult them in the matter. And when you have decided, then rely upon Allah . Indeed, Allah loves those who rely [upon Him]. (QS. Ali Imran [3]: 159) ${ }^{\text {’30 }}$

Dialogue, according to Abdurrahman Wahid, aims to create human who can disregard to races, ethnicity and historical background and to open a way of improving universal values, global commitment, peace culture, and harmony among human being. ${ }^{31}$

\footnotetext{
${ }^{27}$ Wahid, Islamku, Islam Anda, 66

${ }^{28}$ Wahid, Islamku, Islam Anda, 124

${ }^{29}$ Wahid, Islamku, Islam Anda, 125

${ }^{30} \mathrm{https}$ ://quran.com/3/159

${ }^{31}$ Wahid \& Ikeda, Dialog Peradaban, 4.
} 
Dialogue is the only way of taking and giving each other to develop our humanity character. After sharing and believing each other, there will be sharing of feeling and sense of belonging. ${ }^{32}$ And if this feeling and sense of belonging has connected people, there will be no terrorist action. Who wants to hurt the persons we are connected to?

\section{The Importance of Islamic Education}

One of the above reasons is the shallow understanding of young people towards Islam. They also cannot differentiate between the Institution of Islam and the culture of Islam. That's why Abdurrahman Wahid suggested that all Islamic boarding schools (pondok pesantren) education not only to focus on preparing Islamic preachers and scholars, but also focus on building moral and religious practices in each respective area. ${ }^{33}$ This kind of mentality should be changed into positive mentality by aiming all teaching into creating peace values wherever a muslim person lives. One of the ways to change this mentality is through education.

Good education is a pillar of better society and a hope for the better world in the future. Good education prepares the learners to be open minded persons. This openmindedness is the key factor of living in diversity.

Another problem of the fundamentalist who paid more attention to institutional Islam is to change Indonesia's governmental system from democratic to caliph system. According to Abdurrahman Wahid, Islamic education accentuates the justice and prosperity of society, and is more concerned on the holy Qur'an than the system of a governement. He asserted that if this is understood by the people of islams, all the sources of intricacy within islam community will be able to be avoided. ${ }^{34}$

In Indonesia, as far as I am concerned, schools are divided into two, religious schools (Islamic School, Christian School et cetera) and general schools (which do not suffix any religious institution within the name). Abdurrahman Wahid sees that formalist Muslims use Islamic education as a system, namely Islamic system. He argues that indonesian muslim scholars do not agree with such system. They define Islamic education as condescendent for all people regardless of their religion. This has been explained in the Qur'an Surah Al Anbya verse $107^{35}$ "And We have not sent you, [O Muhammad], except as a mercy to the worlds." 36

In islamic education, the spirit of doing religious teaching comes from not only the schools, but also from communication out of schools with all islamic society elements. Islamic education is not only delivered in formal teachings in islamic school, but also in every school in the world. The challange of modernization such as poverty alleviation,

\footnotetext{
${ }^{32}$ Wahid \& Ikeda, Dialog Peradaban,163

${ }^{33}$ Wahid \& Ikeda, Dialog Peradaban, 159

${ }^{34}$ Wahid, Islamku, Islam Anda, 33.

${ }^{35}$ Wahid, Islamku, Islam Anda,78.

${ }^{36} \mathrm{https}$ ://quran.com/21/107, accessed 27/11/2015
} 
preservation of the environtment is much more beneficial and important to be deeply thought. Islamic education's duty is to bring on track what the challanges of modernization are. Unfortunately, that awareness of doing so cannot be found in islamic education everywhere. $^{37}$

Education also can elevate social status of a peson in the society and economics level as a part of terrorism prevention due to poverty is one of the causes. In addition,Educated people are wiser to cope with any problem and friendly with the term of diversity. Awaring of diversity is the root of tolerance.

\section{Reestablishing the systems of the Government}

The government's and society's role to overcome terrorism has shown its result. According Global Terrorism Index 2015, Indonesia is placed in 33th decreasing from the previous year which ranked $31 .^{38}$ Terrorism Index in Indonesia is reported to decrease to 4.43 in 2015 from 4.76 in 2014. It peaked in 2002 with the high of $6.55 .^{39}$

In 2002, Abdurrahman Wahid criticized the governmental policies related to terrorism. the first one is to change the punitive policies into preventive. ${ }^{40}$ At the time, police did not take a defensive action, they tent to incarcerate those who were proven as the terrorist. They did not prevent the action such as not punishing those who held gunfire without license. Whereas one of important components to prevent terror action is the state, police officers in this case.

This condition was exacerbated by the conflict between police officers and army. ${ }^{41}$ Several ocnums of police officers were cought as the backing of drug dealres, gamblers and other crimes. It was hard for society to trust the security force; police and army.

Abdurrahman wahid suggested to giving back society trust to law enforcement officers such as police, judge and others. ${ }^{42}$ He states the importance of law inforcement and freedom in Indonesia and other developing countries which share the same problems in terms of authorities such as corruption, violating the law and denying constitution. His suggestion to do just including to ourselves was based on the Qur' an surah An Nisa verse 135 “ $O$ you who have believed, be persistently standing firm in justice, witnesses for Allah, even if it be against yourselves or parents and relatives. Whether one is rich or poor, Allah is more worthy of both. So follow not [personal] inclination, lest you not be just. And if you distort

\footnotetext{
${ }^{37}$ Wahid, Islamku, Islam Anda, 225.

${ }^{38}$ www.economicsandpeace.org, accessed 25/11/2015

${ }^{39} \mathrm{http}$ ://www.tradingeconomics.com/indonesia/terrorism-index, accessed 25/11/2015

${ }^{40}$ Wahid, Islamku, Islam Anda, 291

${ }^{41} \mathrm{http}$ ://www.suaramerdeka.com/harian/0210/03/nas 1.htmaccessed 25/11/2015

${ }^{42}$ Wahid, Islamku, Islam Anda, 292
} 
[your testimony] or refuse [to give it], then indeed Allah is ever, with what you do, Acquainted." 43 This verse command is clear but Muslims people did not implement the rules that their beloved religion has passed on. ${ }^{44}$

If the government system has been clean and does their functions, terrorims prevention will be more effective and the number of terror action will decrease. The government of Indonesia has been revitalizing their roles from year to year. This gradual process has resulted developments in many sides including security system. And now, under the the hand of Joko Widodo, Indonesia is cleansing the all the officers from the root such as little bribary and exactions between society and officials. If this committment works, society's trust to the governmentis back, it is easier to cope any problems including terrorism.

\section{Conclusion}

Abdurrahman Wahid's soft approach towards terrorism prevention is mainly sourced from the concept of "My Islam, Your Islam, and Our Islam" which contains respecting diversity, doing dialogue, and avoiding violence. In details, the steps to terrorism prevention are many, but here is mentioned three; first is dialogue. Dialogue is the only way to exchange ideas, opinion, and look for the truth. Dialogue is a symbol of democratic country. The second one is to develop the education of Muslims which aims peace regardless of the naming religious affiliation of the school. And the third is reestablishing the system of nation.

Islam nowadays suffers from terrorism illness. A small part of Islam's body is scratched. It tries to heal and care by itself. Since this illness impacts on others than Islam, it is our duty to fights against terrorism in a different way than the terrorists do. If we use violance and physical force, then what is the different between they and us?

More or less, Abdurrahman Wahid's critics, suggestions and opinions influence on the coping mechanism towards terrorism in Indonesia. And I think, I am a bit late to learn about his thought. But it is better late than never.

\footnotetext{
${ }^{43} \mathrm{https}$ //quran.com/4/135, Acessed 25/11/2015

${ }^{44}$ Wahid, Islamku, Islam Anda, 357
} 


\section{Bibliography}

Biggar,Nigel,Between Keen and Cosmopolis, An Ethic of the Nation, Eugene: Wipf and Stock, 2014.

Enders, W., \& Sandler, T. The effectiveness of antiterrorism policies: A vectorautoregression-intervention analysis. The American Political Science Review.,vol. 87, 1993.

Little,David,Peace Makers in Action: Profiles of Religion in Conflic Resolution, Cambridge: Cambridge University Press, 2007.

Wahid, Abdurrahman.Islamku, Islam Anda, Islam Kita:Agama Masyarakat NegaraDemokrasi, Jakarta: The Wahid Institute, 2006.

Wahid, KH. Abdurrahman,\& Ikeda,Daisaku,Dialog Peradaban Untuk Toleransi dan Perdamaian, Jakarta; PT. Kompas Gramedia, 2010

Whittaker, David J., The Terrorism Reader, Oxon: Rouledge, 2007

https://www.britannica.com/biography/Abdurrahman-Wahid

http://www.un.org/documents/ga/res/49/a49r060.htm

http://www.thereligionofpeace.com/pages/articles/opinion-polls.aspx

www.economicsandpeace.org

https://quran.com

http://www.smh.com.au/articles/2004/09/09/1094530774504.html?from=storylhs

http://news.bbc.co.uk/2/hi/asia-pacific/4302368.stm,

http://www.voaindonesia.com/a/a-32-a-2002-05-30-1-1-85128177/10735.html

http://www.tradingeconomics.com/indonesia/terrorism-index

http://www.suaramerdeka.com/harian/0210/03/nas1.htm 
